\title{
Article
}

\section{Roger Martin du Gard and Maumort: The Nobel Laureate and His Unfinished Creation [Book Review]}

Orme, Mark Philip

Available at http://clok.uclan.ac.uk/21820/

Orme, Mark Philip ORCID: 0000-0003-0882-4744 (2018) Roger Martin du Gard and Maumort: The Nobel Laureate and His Unfinished Creation [Book Review]. French History, 32 (1). pp. 140-141. ISSN 0269-1191

It is advisable to refer to the publisher's version if you intend to cite from the work. http://dx.doi.org/10.1093/fh/crx070

For more information about UCLan's research in this area go to http://www.uclan.ac.uk/researchgroups/ and search for < name of research Group>.

For information about Research generally at UCLan please go to http://www.uclan.ac.uk/research/

All outputs in CLoK are protected by Intellectual Property Rights law, including Copyright law. Copyright, IPR and Moral Rights for the works on this site are retained by the individual authors and/or other copyright owners. Terms and conditions for use of this material are defined in the policies page.

\section{CLoK}

Central Lancashire online Knowledge www.clok.uclan.ac.uk

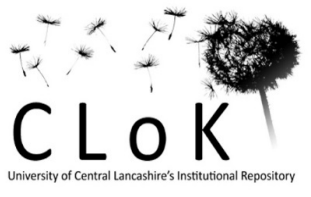


Roger Martin du Gard and Maumort: The Nobel Laureate and his Unfinished Creation. By Benjamin Franklin Martin. DeKalb: Northern Illinois University Press. 2017. $x+233$ pp. \$39. ISBN 978087580 7492.

In this rigorously-researched and well-written volume, Benjamin Franklin Martin sheds light on the life and creative genius of Roger Martin du Gard, a figure who, despite winning the Nobel Prize for Literature in 1937, has become somewhat marginalized in French literary history. Drawing on a myriad of material from Martin du Gard's private journals and personal correspondence with those closest to him, Martin is an engaging guide as he measures the milestones through Martin du Gard's intellectual odyssey. Chapter titles such as 'Illusions', 'Realities', 'Hubris' and 'Retribution' highlight the contradictions and dilemmas underpinning the writer's life story: his emotionally-wrought marriage to Hélène Foucault and the tumultuous relationship with their daughter Christiane; his anguish over trying to reconcile his own moral imperatives with the realities of global conflict; and his propensity towards despair despite his success - all of these examples bear witness to the tensions between the public and the private which this book examines with consummate skill. In parallel with this biographical analysis, Martin also provides an insight into the writer's literary corpus which both the specialist and non-specialist reader will find illuminating. From Jean Barois (1913), Les Thibault and L'Eté 1914 (1922-40) to the unfinished and posthumously published Lieutenant-Colonel de Maumort (1983), Martin du Gard furnishes what Per Hallström of the Swedish Academy called a 'most perfected tool: the analysis of his heroes' thoughts, expressed beyond words, an insight into the darkness which engenders conscious actions' (p. 1). The incomplete Maumort, 'a work of surpassing brilliance' (p. ix), provides an important reference point for Martin, who painstakingly pieces together the fragments of this important work, mirroring Martin du Gard's own history. The work was set to be the writer's magnum opus which, as Martin notes, 'would resurrect the past and parade it for inspection' (p. 117). Through an analysis of the fictional Maumort, the reader is invited to reconsider the legacy of Martin du Gard himself. An so in this book, a writer who has been closely associated with literary luminaries 
such as André Gide, Albert Camus and André Malraux finally receives the attention he undoubtedly deserves in his own right.

University of Central Lancashire Mark Orme 